\title{
Recent Advancement of Understanding Pathogenesis of Type 1 Diabetes and Potential Relevance to Diabetic Nephropathy
}

\author{
Kunihiro Ichinose $^{a}$ Eiji Kawasaki $^{\text {b }}$ Katsumi Eguchi ${ }^{a}$ \\ a Unit of Translational Medicine, Department of Rheumatology, Graduate School of Biomedical Sciences, \\ Nagasaki University, and ${ }^{\mathrm{b}}$ Department of Metabolism/Diabetes and Clinical Nutrition, Nagasaki University \\ Hospital of Medicine and Dentistry, Nagasaki, Japan
}

\section{Key Words}

Type 1 diabetes mellitus • Genetics • Cytokines •

Angiogenesis $\cdot$ Autoimmunity $\cdot$ Inflammation $\cdot$ Diabetic nephropathy $\cdot$ Pathogenesis

\begin{abstract}
Type 1 diabetes mellitus is an autoimmune disease characterized by progressive destruction of pancreatic beta cells by genetic and environmental factors which leads to an absolute dependence of insulin for survival and maintenance of health. Although the majority of mechanisms of beta cell destruction remain unclear, many molecules, including proinflammatory cytokines and chemokines such as tumor necrosis factor alpha and monocyte chemoattractant protein-1, are implicated in the development of beta cell damage. Furthermore, beta cell destruction is enhanced by the Th1 and Th17 subsets of CD4+ T cells. In contrast, there are mechanisms involved in the maintenance of peripheral tolerance by regulatory $T$ cells, the function of which depends on the pleiotropic cytokine transforming growth factor beta. Development and progression of renal injuries in patients with diabetic nephropathy arealso associated with several growth factors and proinflammatory cytokines, including tumor necrosis factor alpha, insulin-like growth factor-1, monocyte chemoattractant protein-1, vascular endothelial growth factor, and transforming growth factor beta. Although the pathogenic mechanisms underlying type 1 diabetes and di-
\end{abstract}

\section{KARGER}

Fax +41613061234

E-Mail karger@karger.ch

www.karger.com
(C) 2007 S. Karger AG, Basel

0250-8095/07/0276-0554\$23.50/0

Accessible online at:

www.karger.com/ajn abetic nephropathy are principally different, i.e., autoimmunity and inflammation, some common factors, including susceptibility genes and proinflammatory cytokines, are involved in both mechanisms, including infiltrating cell recruitment, upregulation of other cytokines and chemokines, or apoptosis.

Copyright $\odot 2007$ S. Karger AG, Basel

\section{Introduction}

Diabetes mellitus is a complex syndrome characterized by absolute or relative insulin deficiency that leads to hyperglycemia and an altered glucose, fat, and protein metabolism. These metabolic dysfunctions are associated pathologically with specific microvascular diseases secondary to accelerated atherosclerosis and various other characteristic long-term complications, including diabetic retinopathy, nephropathy, and neuropathy. It has been clearly established that diabetes mellitus is a genetically and clinically heterogeneous disorder. Four types of diabetes mellitus have been defined by an Expert Committee on the Diagnosis and Classification of Diabetes Mellitus [1] and a WHO consultation [2], based on our current understanding of the pathogenesis rather than the requirement for insulin therapy: type 1 diabetes mellitus, type 2 diabetes mellitus, gestational diabetes mellitus, and diabetes secondary to other conditions.

Eiji Kawasaki, MD, PhD

Department of Metabolism/Diabetes and Clinical Nutrition

Nagasaki University Hospital of Medicine and Dentistry, 1-7-1 Sakamoto Nagasaki 852-8501 (Japan)

Tel. +8195849 7550, Fax +8195849 7552, E-Mail eijikawa@nagasaki-u.ac.jp 
Table 1. Multiple causes of insulin-deficient diabetes

\begin{tabular}{lll}
\hline Disorder & Genetic abnormality & Extrapancreatic disease manifestations \\
\hline Type 1A diabetes & MHC and non-MHC genes & Organ-specific autoimmune disease \\
Type 1B diabetes & $?$ & No \\
MODY-1 & Hepatocyte nuclear factor-4 $\alpha$ gene & No \\
MODY-3 & Hepatocyte nuclear factor-1 $\alpha$ gene & No \\
MODY-6 & NeuroD1 gene & No \\
Wolfram syndrome & WFS1 gene & Neuronal \\
Kearns-Sayre syndrome & Mitochondrial DNA deletion & Neuronal \\
MELAS & Mitochondrial DNA mutation & Hearing loss \\
\hline
\end{tabular}

MODY = Maturity-onset diabetes of the young; MELAS = mitochondrial myopathy, encephalopathy, lactic acidosis, and stroke-like episodes.

Type 1 diabetes is an organ-specific autoimmune disease characterized by a progressive cell-mediated destruction of beta cells of the pancreas which leads to an absolute dependence on insulin for survival and maintenance of health. In contrast, type 2 diabetes is a nonautoimmune form of diabetes characterized by insulin resistance and relative (rather than absolute) insulin deficiency. Both forms of the disease may exist in the same family, and persons with either type are subject to the same long-term complications, including diabetic nephropathy which affects $\sim 40 \%$ of the patients. It has been reported [3] that hyperglycemia, increased blood pressure, and genetic predisposition are the main risk factors for the development of diabetic nephropathy. There is increasing evidence for the role of genetic factors in the development of diabetic nephropathy [3]. Furthermore, recent studies suggest that inflammatory processes and immune system cells might be involved in development and progression of diabetic nephropathy. There is a growing body of evidence implicating inflammatory cells at every stage of diabetic nephropathy which produce various reactive oxygen species, proinflammatory cytokines, metalloproteinases, and growth factors that are also associated with the development of type 1 diabetes. The aim of this article is to discuss the current knowledge on the pathogenesis of type 1 diabetes and its potential relevance to the development of diabetic nephropathy.

\section{Classification of Type 1 Diabetes}

Type 1 diabetes is a heterogeneous disease and is subdivided into two groups, i.e., immune system mediated and idiopathic type 1 diabetes. It has been reported [4] that $>80 \%$ of the patients with type 1 diabetes have the immune sytem mediated (type 1A) form. To date, the detection of autoantibodies against multiple islet autoantigens in the serum is a sole hallmark of type $1 \mathrm{~A}$ diabetes [4]. Among the increasing number of anti-islet autoantibodies in type $1 \mathrm{~A}$ diabetes, autoantibodies against glutamic acid decarboxylase 65 (GAD65), insulinoma-associated antigen-2 (IA-2), and insulin have been shown to be relevant to the diagnosis. The detection of at least one autoantibody provides evidence of an ongoing autoimmune process. However, negative autoantibodies do not completely exclude the presence of type 1 diabetes. Some of these patients have permanent insulinopenia and are prone to ketoacidosis, but have no evidence of autoimmunity. This form of diabetes is classified as the idiopathic (type 1B) form which accounts for $10-20 \%$ of the type 1 diabetes patients.

Several disorders other than type 1 diabetes also lead to severe pancreatic islet beta cell dysfunction. Within the past decades, an increasing number of genetic disorders have been defined which are associated with insulindeficient diabetes [4]. These disorders often have characteristic inheritance patterns or extrapancreatic disease manifestations. Several of these disorders are listed in table 1. MODY (maturity-onset diabetes of the young) is caused by mutations in hepatocyte nuclear factor- $4 \alpha$ gene [5], glucokinase gene [6], hepatocyte nuclear factor-1 $\alpha$ gene [7], insulin promoter factor-1 gene [8], hepatic transcription factor-2 gene [9], NeuroD1 gene [10], and KLF11 gene [11]. The disorder appears not to be progressive, and these individuals usually require no specific therapy. Their diabetes can manifest in childhood or later in life, and many of these individuals behave as insulin-dependent patients, even though they have no evidence of au- 
Table 2. IDDM loci for type 1 diabetes

\begin{tabular}{lll}
\hline IDDM & Locus & Candidate gene \\
\hline IDDM1 & $6 \mathrm{q} 21.3$ & Class II HLA \\
IDDM2 & $11 \mathrm{p} 15$ & Insulin VNTR \\
IDDM3 & $15 \mathrm{q} 26$ & \\
IDDM4 & $11 \mathrm{q} 13$ & LDL-receptor-related protein 5 \\
IDDM5 & $6 \mathrm{q} 25$ & SUMO4 \\
IDDM6 & $18 \mathrm{q} 12-\mathrm{q} 21$ & \\
IDDM7 & $2 \mathrm{q} 31-\mathrm{q} 33$ & \\
IDDM8 & $6 \mathrm{q} 27$ & \\
IDDM9 & $3 \mathrm{q} 22-\mathrm{q} 25$ & CD80 or CD86 \\
IDDM10 & $10 \mathrm{p} 11-\mathrm{q} 11$ & \\
IDDM11 & $14 \mathrm{q} 24-\mathrm{q} 31$ & \\
IDDM12 & $2 \mathrm{q} 33$ & CTLA-4 \\
IDDM13 & $2 \mathrm{q} 34$ & \\
IDDM14 & - & \\
IDDM15 & $6 \mathrm{q} 21$ & \\
IDDM16 & $14 \mathrm{q} 32.3$ & \\
IDDM17 & $10 \mathrm{q} 25$ & \\
IDDM18 & $5 \mathrm{q} 31-\mathrm{q} 33$ & IL-12 $p 40$ \\
\hline
\end{tabular}

toimmunity. With their insulin dependence and their severe hyperglycemia, patients with MODY are at risk of developing chronic microvascular and macrovascular complications.

In contrast to MODY, patients with several of the other syndromes listed in table 1 have some extrapancreatic disease manifestations. Patients with Wolfram's syndrome have a median survival of 30 years and develop progressive neurological dysfunction (DIDMOAD: diabetes insipidus, diabetes mellitus, optic atrophy, and deafness) [12-14]. The disorder has been linked to mutations of the WSF1 gene on chromosome 4 which has an important function in maintaining the homeostasis of the endoplasmic reticulum in pancreatic beta cells $[12,14$, 15]. The maternally inherited diabetes mellitus is characterized by a point mutation in the mitochondrial gene coding for tRNA ${ }^{\mathrm{LEU}(\mathrm{UUR})}$ (especially at nucleotide position 3243) and is associated with nerve deafness and a lower insulin-secretory capacity [16].

\section{Genetics of Type 1 Diabetes}

Although the etiology of type 1 diabetes is only partially characterized, it is recognized that both genetic and environmental factors are involved in the development of the disease. Many studies have shown that the human leukocyte antigen (HLA) class II loci on chromosome 6q21.3, including $H L A-D R B 1, H L A-D Q B 1$, and $H L A-$ $D Q A 1$, are most strongly associated with diabetes risk and may account for nearly $40 \%$ of the familial aggregation of type 1 diabetes. These HLA region susceptibility genes are collectively referred to as IDDM1. Furthermore, more than 20 putative diabetes-predisposing genes have been identified by linkage and association studies (table 2). Recent combined analysis of four datasets using a large number of multiplex families provided evidence for linkage of type 1 diabetes to nine non-HLA-linked regions, including 6q21 (IDDM15), 2q31-q33 (IDDM12 and IDDM7), 10p14-q11 (IDDM10), 11p15 (IDDM2), and 16q22-q24 [17]. The genes responsible for IDDM2 and IDDM12 have been identified based on genetic association studies as a variable number of tandem repeats (VNTR) in insulin gene and cytotoxic T lymphocyte antigen-4 (CTLA-4) gene, respectively. Additional previously reported non-HLA genes include PTPN22 gene (chromosome 1p13), SUMO4 gene (chromosome 6q25), and $I L-18$ gene (chromosome 11q22) [18].

\section{Immune Mechanisms Responsible for Islet Cell Loss}

Activation of the T-cell-mediated immune system in genetically susceptible individuals leads to a lymphocytic infiltration within the islets (insulitis) as well as to a humoral ( $\mathrm{B}$ cell) response with production of antibodies against one or more beta cell autoantigens. The model of the natural history of type 1 diabetes suggests that there is a long prodromal phase preceding the onset of clinical symptoms in type 1 diabetes (fig. 1). Overt diabetes clinically manifests only after destruction of approximately $90 \%$ of the beta cells [4]. The initial interaction of genes and environmental factors, such as viral infections, trigger an immune response to islet autoantigens, with the emergence of autoantibodies as the first sign of beta cell destruction, followed by progressive loss of the first-phase insulin secretion [19]. To date, the best autoantibody predictor of a high type 1 diabetes risk is the expression of multiple anti-islet autoantibodies. Among autoantibodies against insulin, GAD65 and IA-2, expression of a single autoantibody was associated with an approximate $20 \%$ risk of diabetes within 10 years of follow-up. In contrast, expression of multiple autoantibodies was associated with a very high risk of progression. The 'combinatorial' analysis allowing more than two autoantibodies to be defined, independent of which two autoantibodies are expressed, gives approximately an $80 \%$ sensitivity for progression to diabetes with a very high specificity $[20$, 
Fig. 1. Schematic representation of the natural history of type 1 diabetes. The initial interaction of HLA and non-HLA genes and environmental factors trigger an autoimmune response to islet autoantigens, with the emergence of multiple anti-islet autoantibodies, followed by the progressive loss of the insulin release. Over time, there is impaired glucose tolerance and ultimately overt diabetes. Several years after the onset of type 1 diabetes, the beta cell mass is completely or near completely lost. IAA = Insulin autoantibodies; GADAb = GAD65 autoantibodies; IA-2Ab = IA-2/ ICA512 autoantibodies; ICA = islet cytoplasmic autoantibodies.

Fig. 2. Mechanisms of beta cell destruction in type 1 diabetes. T-cell-mediated beta cell destruction is induced by the release of cytotoxic molecules, including cytokines, granzyme B, or perforin, or by direct delivery of cell death signals via the Fas pathway. Beta cells die through an apoptotic process which is activated by Fas interaction with Fas ligand and action of nitric oxide and oxygen free radicals, perforin, and granzyme B. T cell cytokines, including IL-1, IFN- $\gamma$, and TNF- $\alpha$, exacerbate beta cell death. In contrast, CD4+CD25+ Foxp3+-regulatory T cells will suppress effector T cells via cell-cell contact.
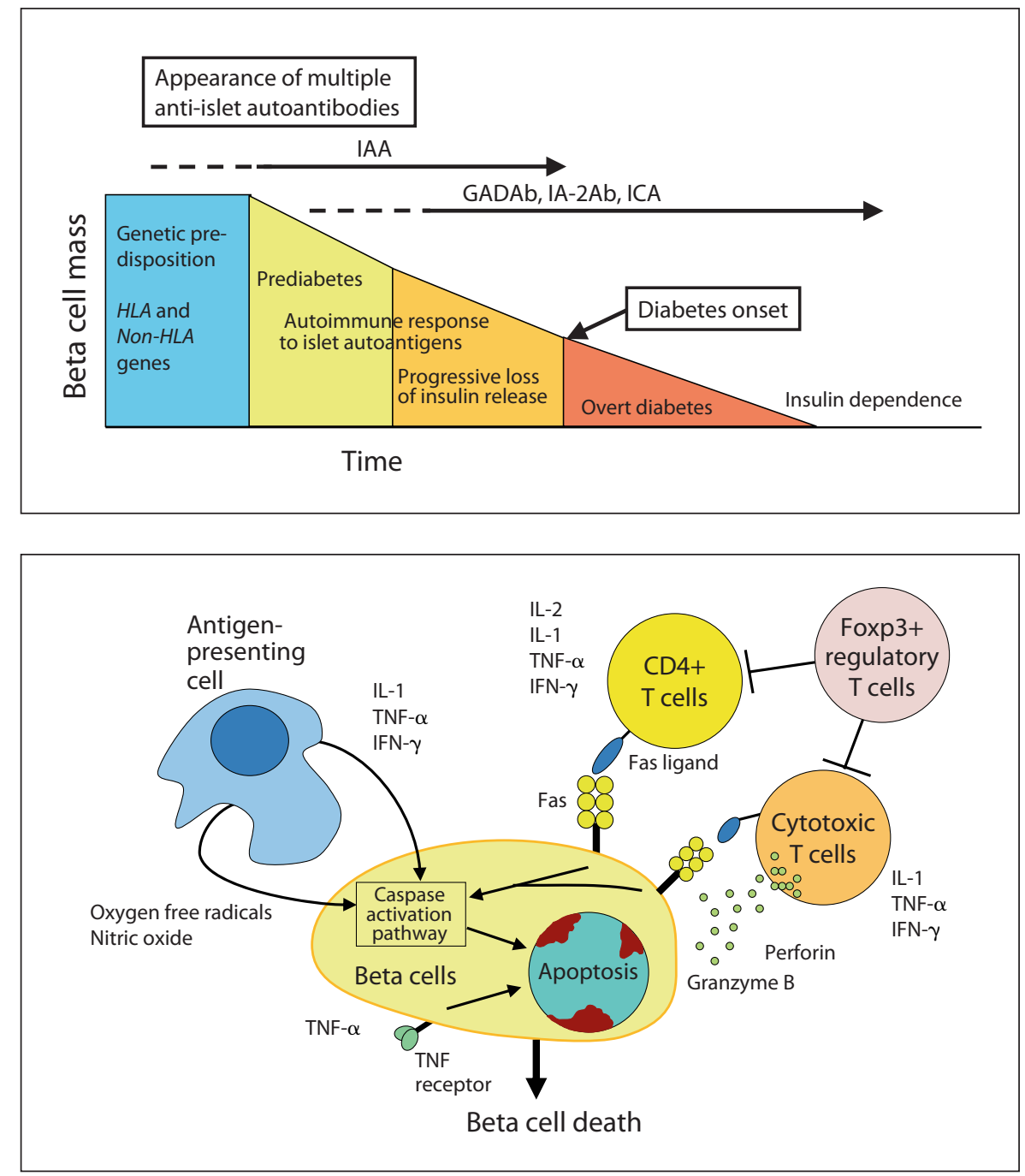

21]. The progression to overt diabetes resulting in a significant beta cell destruction is triggered by the development of a more aggressive $T$ cell phenotype and a change in the Th1-to-Th2 balance towards a more proinflammatory milieu (Th1 dominant). Furthermore, evidence demonstrating the association of the Th17 subset, the recently discovered CD4+ effector T cell lineage distinct from Th1 and Th2, with pathogenesis of type 1 diabetes is rapidly accumulating [22-24].

T-cell-mediated beta cell destruction is induced by the release of cytotoxic molecules, including cytokines, granzyme B, or perforin, or by direct delivery of cell death signals via the Fas pathway $[25,26]$. Activated CD4+ and CD8+ T cells act in unison to activate beta cell death via apoptosis. Apoptosis is introduced by activation of the caspase pathway which, in turn, is activated by a number of alternative mechanisms such as Fas interaction with Fas ligand, action of nitric oxide and oxygen-derived free radicals, and membrane disruption by perforin and granzyme B produced by cytotoxic T cells. T cell cytokines, including IL-1, IFN- $\gamma$, and TNF- $\alpha$, exacerbate beta cell death by upregulation of Fas and Fas ligand and stimulation of nitric oxide and free radical production. Various cytokines are involved in the enhancement beta cell damage in type 1 diabetes [27]. Beta cell destruction is enhanced by the Th1 and Th17 subsets of CD4+ T cells and cytokines, such as INF- $\gamma$, TNF- $\alpha$, and IL-2, IL-12, IL-17, and IL-18 (fig. 2). In patients with type 1 diabetes, infiltration of mononuclear cells consisting of $\mathrm{CD} 4+$ and CD8+ T cells, B cells, and macrophages is observed in islets of pancreas biopsy specimens [28]. 
Fig. 3. Molecular mechanisms of diabetic nephropathy. Hyperglycemia activates angiogenesis and induces profibrotic factors, metabolic factors, and hemodynamic factors. VEGF may increase the glomerular capillary number on the endothelial cell and relax the afferent arteriolar tone (through endothelial nitric oxide synthase), generating hemodynamic forces that can induce glomerular hyperfiltration. Monocyte/macrophage accumulation in the glomeruli may be induced by VEGF via vascular permeability. TGF- $\beta$ induces profibrotic stimuli and leads to mesangial matrix expansion. Angiotensin II activity is involved in podocyte injury and suppression of nephrin in diabetes. AGE $=$ Advanced glycation end products; MCP-1 = monocyte chemoattractant protein-1; ECM = extracellular matrix; GBM = glomerular basement membrane; $\mathrm{PKC}=$ protein kinase C. For explanation of the other abbreviations see text.

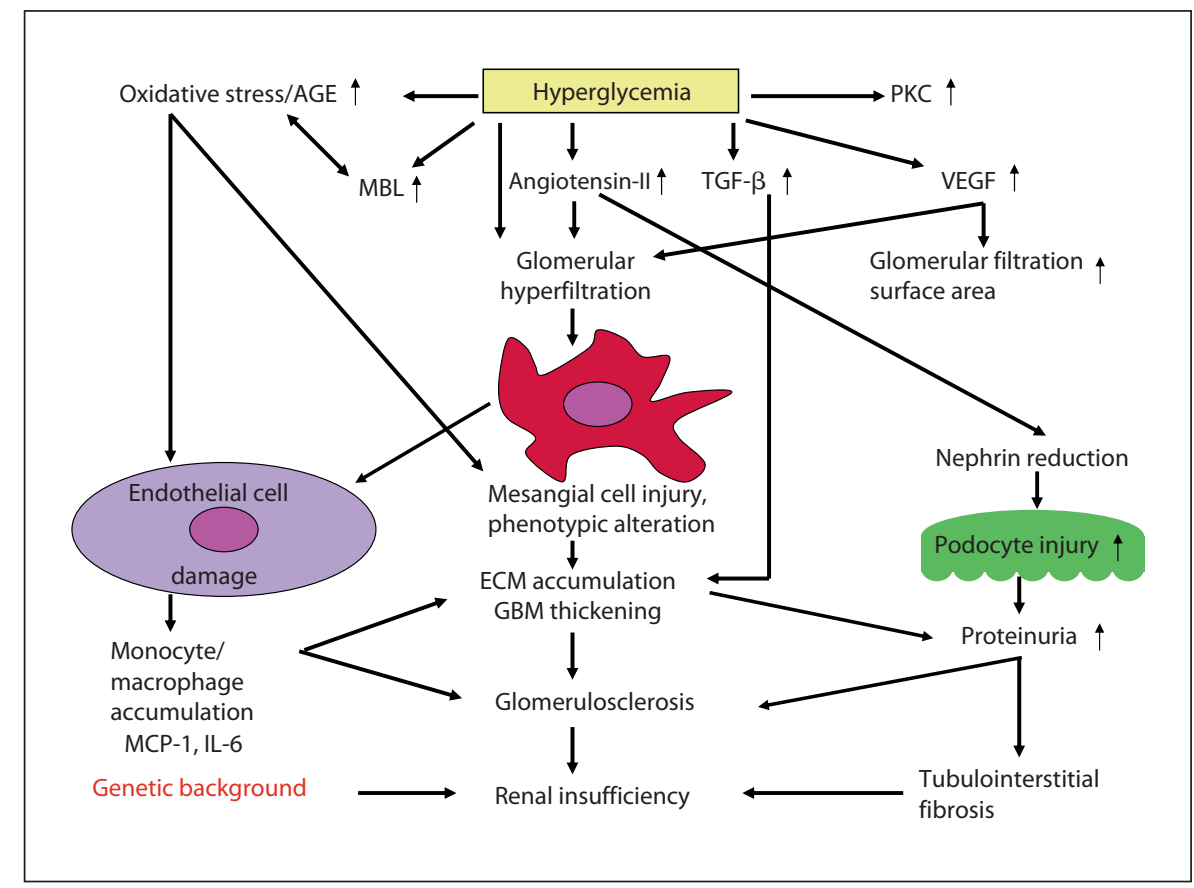

In contrast, there are mechanisms involved in the maintenance of peripheral tolerance by a specialized subset of regulatory $\mathrm{T}$ cells (Tregs). CD4+ Tregs that constitutively coexpress the IL-2R $\alpha$ chain $(\mathrm{CD} 4+\mathrm{CD} 25+)$ have been shown to play a critical role in controlling undesired immune responses to self-antigens [29]. A member of the forkhead family of transcription factors, FOXP3, has been shown to be expressed in murine and human CD4+CD25+ Tregs and appears to be a master gene controlling CD4+CD25+ Treg development [30]. $\mathrm{CD} 4+\mathrm{CD} 25+$ Tregs with a reduced in vitro suppressive function were found in some studies performed on patients with type 1 diabetes $[31,32]$. Treg development and function depend on the pleiotropic cytokine TGF- $\beta$ which is also linked to Th17 cell development $[22,23]$.

\section{Pathogenesis of Diabetic Nephropathy}

Hyperglycemia is a most important factor in the progression of diabetic nephropathy. Early alterations in diabetic nephropathy include glomerular hyperfiltration, glomerular and tubular epithelial hypertrophy, and the development of microalbuminuria, followed by the development of glomerular basement membrane thickening, accumulation of mesangial matrix, and overt proteinuria, eventually a leading cause of glomerulosclerosis and end-stage renal disease [33]. The accumulation of matrix in the mesangial area reduces the capillary surface area available for filtration, thereby contributing to the progressive loss of the renal function [34]. Hyperglycemia-induced metabolic and hemodynamic factors are thought to be mediators of this injury. The hemodynamic factors implicated in the pathogenesis of diabetic nephropathy include increased systemic and intraglomerular pressure and activation of various vasoactive hormone pathways, including the renin-angiotensin system and endothelins. Multiple biochemical pathways may interact with the metabolic pathway: activated advanced glycation end products, protein kinase $C$, acceleration of the polyol pathway, and overexpression of TGF- $\beta$ (fig. 3 ).

\section{Podocyte Damage and Nephrin Loss}

Recent data suggest that the podocytes, specialized visceral epithelial cells, are important for the maintenance of the dynamic functional barrier [35], and the number of podocytes may be reduced in the glomeruli of both type 1 and type 2 diabetic patients [36, 37]. Furthermore, it has been reported that nephrin, a recently found podocyte protein, is crucial for maintaining the integrity of the interpodocyte slit membrane structure and for maintenance of an intact filtration barrier. In diabetic nephropathy, the protein level of nephrin decreases, possibly via loss into the urine due to synthesis of splice variant isoforms of the 
Table 3. Candidate genetic determinants for diabetic nephropathy

\begin{tabular}{|c|c|c|c|}
\hline Symbol & Name & Locus & Rationale \\
\hline SLC12A3 [91] & $\begin{array}{l}\text { Solute carrier family } 12 \text { member } \\
\text { (sodium/chloride) } 3\end{array}$ & $16 \mathrm{q} 13$ & $\begin{array}{l}\text { The } S L C 12 \mathrm{~A} 3 \text { gene encodes a thiazide-sensitive } \mathrm{Na}^{+}-\mathrm{Cl}^{-} \\
\text {cotransporter that mediates reabsorption of } \mathrm{Na}^{+} \text {and of } \mathrm{Cl}^{-} \\
\text {at the renal distal convoluted tubule }[91,92]\end{array}$ \\
\hline ELMO1 [55] & Engulfment and cell motility 1 & $7 \mathrm{p} 14.1$ & $\begin{array}{l}\text { ELMO1 contributes to glomerular injury through dysregulation } \\
\text { of the ECM metabolism and reduction in cell-adhesive properties } \\
\text { to ECMs }[55,93]\end{array}$ \\
\hline ICAM-1 $[85]^{*}$ & Intracellular adhesion molecule & $19 \mathrm{p} 13$ & $\begin{array}{l}\text { Increased ICAM-1 expression accompanies progression of type } 1 \\
\text { diabetes and diabetic nephropathy [94-96] }\end{array}$ \\
\hline$V E G F[97]^{*}$ & Vascular endotherial growth factor & $6 \mathrm{p} 12$ & $\begin{array}{l}\text { VEGF expression increased in glomeruli of diabetic animals; } \\
\text { anti-VEGF therapy reduced AER and hyperfiltration }[43,63,64]\end{array}$ \\
\hline$M B L 2[98]^{*}$ & Mannose-binding lectin & $10 \mathrm{q} 11.2-\mathrm{q} 21$ & $\begin{array}{l}\text { The MBL pathway of complement activation may contribute to } \\
\text { the development of diabetic microvascular complications }[98,99]\end{array}$ \\
\hline SUMO4 $[83]^{*}$ & Small ubiquitin-like modifier 4 & $6 q 25$ & $\begin{array}{l}\text { SUMO mRNA is mainly expressed in kidneys and immune } \\
\text { system [100] }\end{array}$ \\
\hline$T N F-\alpha[101]^{*}$ & Tumor necrosis factor- $\alpha$ & $6 \mathrm{p} 21.3$ & $\begin{array}{l}\text { The level of expression of TNF- } \alpha \text { correlated with obesity and } \\
\text { hyperinsulinemia [102] }\end{array}$ \\
\hline$T G F-\beta[86]^{*}$ & Transforming growth factor- $\beta 1$ & $19 q 13.1$ & $\begin{array}{l}\text { TGF- } \beta \text { mRNA and proteins (and TGF- } \beta \text { receptor mRNA) } \\
\text { identified in rodent glomerular cells [103-105] }\end{array}$ \\
\hline$M C P-1[84]^{*}$ & Monocyte chemotactic protein-1 & 17q11.2-q12 & $\begin{array}{l}\text { MCP-1 is produced in response to proinflammatory stimuli and } \\
\text { high glucose level in mesangial cells [106] }\end{array}$ \\
\hline
\end{tabular}

nephrin lacking a transmembrane domain $[38,39]$. Several studies have been performed on the angiotensin II activity which is involved in podocyte injury in diabetes. Angiotensin-converting enzyme inhibitors prevented loss of podocytes and podocyte injury in the streptozotocininduced diabetic rat. In addition to angiotensin-converting enzyme inhibitors, angiotensin II type 1 receptor antagonism attenuated podocyte foot process broadening in the streptozotocin-induced diabetic rat $[40,41]$.

Although mesangial cells and podocytes are proposed as the major mediators of diabetic nephropathy, several growth factors and cytokines, including insulin-like growth factor-1, monocyte chemoattractant protein-1 (MCP-1), and IL-6, also play a key role in the pathogenesis, but most importantly vascular endothelial growth factor (VEGF) and TGF- $\beta$. VEGF, a potent stimulator of angiogenesis, promotes endothelial cell proliferation and migration and endothelial tube formation [42]. The protein and mRNA levels of VEGF and its receptor flk-1/KDR are upregulated in experimental diabetic nephropathy [4345] (fig. 3).

Type 1 Diabetes and Diabetic Nephropathy

\section{Genetics}

There is also growing evidence that the genetic background determines the risk of nephropathy in patients with diabetes. Epidemiologic studies have shown that $35 \%$ of the patients with diabetes develop nephropathy, irrespective of glycemic control [46,47]. Since only 1 in 3 individuals with type 1 diabetes ever developed diabetic nephropathy, both environmental and genetic factors have been postulated as the mechanisms that determine who develops hyperglycemia-related glomerular injury. Familial clustering of diabetic nephropathy has also been demonstrated by several investigators [48-50].

There are only a few descriptions of genomewide scans for diabetic nephropathy, and the number of the analyses would not be enough. In the genomewide scans for microvascular complications in Pima Indians, four loci on chromosomes 3, 7, 9, and 20 were identified [51]. A candidate gene study of type 1 diabetic nephropathy also identified a 63-cM region on chromosome 3q, containing the angiotensin II type 1 receptor gene [52]. Furthermore, other linkage studies identified additional loci on chro- 
mosomes 7q21.3, 10p15.3, 14q23.1, and 18q22.3 as diabetic nephropathy susceptibility genes $[53,54]$. Recently, a high-throughput system for genotyping single-nucleotide polymorphisms has been developed, and genomewide association studies using more than 80,000 singlenucleotide polymorphisms to pinpoint loci involved in the susceptibility to diabetic nephropathy were performed in the Japanese population. Using this system, several candidate genes, including solute carrier family 12 member 3 (SLC12A3) gene on chromosome 16q13 and engulfment and cell motility-1 (ELMO1) gene on chromosome 7p14, were identified $[55,56]$.

Candidate-gene-based association studies have been the most common approaches employed to identify susceptibility genes for diabetic nephropathy. The genes encoding for angiotensin-converting enzyme, angiotensin II receptor, glucometabolism, lipids, extracellular matrix, and cytokines have been selected to test for an association with diabetic nephropathy based on our current understanding of the pathogenesis of the disease. To date, a number of single-nucleotide polymorphisms are reported as diabetic nephropathy susceptibility genes [57]. Candidate genetic determinants for diabetic nephropathy are provided in table 3 .

\section{Angiogenic and Proinflammatory Factors}

Recent studies suggest that an inflammatory mechanism mediated by macrophages and angiogenesis may play important roles in the pathogenesis of diabetic nephropathy. Relatively recent reports [58-60] described that the degree of neovascularization was significantly increased in patients with diabetic nephropathy and correlates with the expression of VEGF and angiopoietin which likely contribute to diabetic nephropathy by promoting vessel leakage and reducing transendothelial electrical resistance. The angiogenic growth factor VEGF induces the activation of matrix-degrading protease represented by matrix metalloproteases and migration and proliferation of endothelial cells [42]. Recent animal studies utilizing a neutralizing anti-VEGF antibody further demonstrated the involvement of this factor in early glomerular hypertrophy and mesangial matrix accumulation in the progressive stage of diabetic nephropathy [61, 62]. We have previously reported the therapeutic efficacy of endostatin peptide, a potent inhibitor of VEGF, which ameliorates renal alterations in the early stage of type 1 diabetic nephropathy. Increased accumulation of monocytes/macrophages in glomeruli has been reported in diabetic nephropathy [63-65]. Considering the effect of VEGF in promoting vascular permeability, it is possible that this may be partially mediated via stimulation of VEGF. In our study, increased expression of IL- 6 and MCP-1 in diabetic glomeruli was suppressed by antiangiogenic treatment, suggesting that the cytokines may mediate monocyte/macrophage infiltration. It has also been shown that VEGF increases the survival of pancreatic islets and thus beta cell sparing after islet transplantation by stimulating angiogenesis and improving islet revascularization [66, 67]. Moreover, transgenic mice that overexpress VEGF are characterized by islet hyperplasia, suggesting that VEGF modulates endocrine pancreatic differentiation [68]. Whether this cytokine also protects from the autoimmune destruction of beta cells is currently unknown.

Another angiogenesis-associated factor, angiopoietin-1, is involved in the attachment of mesenchymal cells to endothelial tubes and in the differentiation to mature pericytes, so-called 'nonleaky' blood vessels [69]. Angiopoietin-2 is the natural antagonist of angiopoietin-1 and loosens the attachment of pericytes, resulting in the promotion of sprouting angiogenesis in the presence of VEGF. Angiopoietin-1 is an apparent endogenous VEGF inhibitor, and angiopoietin-2 synergizes with VEGF and is upregulated in diabetic microvascular complications [70]. However, the involvement of angiopoietin-1 and angiopoietin-2 in the progression of diabetic nephropathy has yet to be elucidated.

TGF- $\beta$ has been recognized as a profibrotic growth factor involved in the expansion of mesangial matrix and renal hypertrophy in diabetic nephropathy [71]. Elevated levels of TGF- $\beta$ have been measured in the glomeruli of streptozotocin-diabetic rats [72]. It was reported [73] that neutralizing TGF- $\beta$ antibody prevented diabetic renal atrophy, mesangial matrix expansion, and the development of renal insufficiency in type $2 d b / d b$ mice. Certain TGF$\beta$-inducible genes, such as connective tissue growth factor and heat shock protein 47, appear to exert fibrogenic effects on diabetic kidneys [74-77]. Moreover, serum and urinary TGF- $\beta$ levels have been found to correlate with the severity of microalbuminuria.

\section{Correlation of Pathogenesis between Type 1 Diabetes and Diabetic Nephropathy}

The hallmark of type 1 diabetes is the selective destruction of insulin-producing islet beta cells by activated $\mathrm{T}$ cells. It has been reported $[78,79]$ that activated $\mathrm{T}$ cells are also associated with diabetic nephropathy. T cell accumulation is found in the juxtaglomerular apparatus of 
patients with type 1 diabetes. T cell influx would become the factor to exacerbate diabetes and correlates with glomerular filtration surface and albumin excretion rate. Expression of the adhesion molecules lymphocyte-function-associated antigen-1 and ICAM- 1 is found on renal endothelial, epithelial, and mesangial cells, and $\mathrm{T}$ cell $\mathrm{mi}-$ gration into kidney needs these interactions. IFN- $\gamma$ secretion by $\mathrm{T}$ cells can initiate and induce further inflammation and oxidative stress within renal tissues [80]. There are several cytokines associated with the development of the pancreatic beta cell destruction and diabetic nephropathy. It has been reported $[81,82]$ that the serum levels of IL-18 and TNF- $\alpha$ are elevated in patients with diabetic nephropathy. IL-18 is a potent proinflammatory cytokine that induces IFN- $\gamma$ and TNF- $\alpha$, and these cy tokines are also associated with the beta cell destruction in type 1 diabetes. Furthermore, as described above, a profibrotic growth factor, TGF- $\beta$, is an important pleiotropic cytokine associated with the development of Tregs and Th17 cells. Collectively, in diabetes, induction of proinflammatory and profibrogenic molecules is responsible for dysregulation of both systemic and renal structural and function abilities.

Furthermore, many genetic determinants involved in both type 1 diabetes and diabetic nephropathy are also reported (table 3). One of the loci identified as diabetic nephropathy susceptibility genes, $18 \mathrm{q} 22.3$, is located near the type 1 diabetes susceptibility loci (IDDM6). Among the genetic variants listed in table 3, ICAM-1 gene, VEGF gene, MBL2 gene, SUMO4 gene, TNF- $\alpha$ gene, TGF- $\beta$ gene, and MCP-1 gene have been reported as common genetic determinants for the development of both type 1 diabetes and diabetic nephropathy [83-87].

Mannose-binding lectin (MBL; also known as mannan-binding lectin) is associated with overt diabetic nephropathy. MBL can activate the complement system independent of antibodies via MBL-associated serine proteases [88]. Through thispathway, MBL playsan important role in the innate immune system which leads to autoimmunity either by priming or by promoting aggressive immune responses. Recent reports have suggested increased levels of serum MBL and MBL complex activity in type 1 diabetic patients [89] and in diabetic patients with diabetic nephropathy [90; for references 91-106 see table 3]. Therefore, it leads to the speculation that MBL is involved in the pathogenesis of type 1 diabetes by assisting the autoimmune process of insulitis as well as the development of diabetic nephropathy.

\section{Conclusions}

The development of both type 1 diabetes (beta cell injury) and diabetic nephropathy (glomerular injury) is determined by environmental and genetic factors. A vast amount of information has been collected through the years regarding the molecular mechanisms involved in developing type 1 diabetes or diabetic nephropathy. Although the pathogenic mechanisms underlying type $1 \mathrm{di}-$ abetes and diabetic nephropathy are principally different, i.e., autoimmunity and inflammation, some common factors, including susceptibility genes and proinflammatory cytokines, are involved in both mechanisms including infiltrating cell recruitment, upregulation of other cytokines and chemokines, or apoptosis. These include SUMO4, MCP-1, TGF- $\beta$, TNF- $\alpha$, IL-18, and MBL, etc. Therefore, the research for clarifying the pathogenesis of microvascular complications in diabetes may lead to the unexpected new findings for the understanding the etiology of type 1 diabetes.

\section{Acknowledgments}

We would like to thank Yohei Maeshima, MD, $\mathrm{PhD}$, for his detailed comments, suggestions, and constant support. This work was partially supported by a Grant-in-Aid for Scientific Research from the Ministry of Education, Culture, Science, Sports and Technology of Japan.

\section{References}

1 Report of the Expert Committee on the Diagnosis and Classification of Diabetes Mellitus. Diabetes Care 1997;20:1183-1197.

$\checkmark 2$ Alberti KG, Zimmet PZ: Definition, diagnosis and classification of diabetes mellitus and its complications. 1. Diagnosis and classification of diabetes mellitus provisional report of a WHO consultation. Diabet Med 1998;15: 539-553.

3 Bowden DW: Genetics of diabetes complications. Curr Diab Rep 2002;2:191-200.

4 Kawasaki E, Gill RG, Eisenbarth GS: Type 1 Diabetes Mellitus. Austin, Landes Bioscience, 1999.

$\checkmark 5$ Yamagata K, Furuta H, Oda N, Kaisaki PJ, Menzel S, Cox NJ, Fajans SS, Signorini S, Stoffel M, Bell GI: Mutations in the hepatocyte nuclear factor-4alpha gene in maturityonset diabetes of the young (MODY1). Nature 1996;384:458-460.

6 Froguel P, Zouali H, Vionnet N, Velho G, Vaxillaire M, Sun F, Lesage S, Stoffel M, Takeda J, Passa P, Permutt MA, Beckmann JS, Bell GI, Cohen D: Familial hyperglycemia due to mutations in glucokinase: definition of a subtype of diabetes mellitus. N Engl J Med 1993;328:697-702. 
-7 Yamagata K, Oda N, Kaisaki PJ, Menzel S, Furuta H, Vaxillaire M, Southam L, Cox RD, Lathrop GM, Boriraj VV, Chen X, Cox NJ, Oda Y, Yano H, Le Beau MM, Yamada S, Nishigori H, Takeda J, Fajans SS, Hattersley AT, Iwasaki N, Hansen T, Pedersen O, Polonsky KS, Bell GI, et al: Mutations in the hepatocyte nuclear factor-1alpha gene in maturity-onset diabetes of the young (MODY3). Nature 1996;384:455-458.

8 Fajans SS, Bell GI, Polonsky KS: Molecular mechanisms and clinical pathophysiology of maturity-onset diabetes of the young. N Engl J Med 2001;345:971-980.

-9 Horikawa Y, Iwasaki N, Hara M, Furuta H, Hinokio Y, Cockburn BN, Lindner T, Yamagata K, Ogata M, Tomonaga O, Kuroki H, Kasahara T, Iwamoto Y, Bell GI: Mutation in hepatocyte nuclear factor-1 beta gene (TCF2) associated with MODY. Nat Genet 1997; 17:384-385.

-10 Malecki MT, Jhala US, Antonellis A, Fields L, Doria A, Orban T, Saad M, Warram JH, Montminy M, Krolewski AS: Mutations in NEUROD1 are associated with the development of type 2 diabetes mellitus. Nat Genet 1999;23:323-328.

-11 Neve B, Fernandez-Zapico ME, AshkenaziKatalan V, Dina C, Hamid YH, Joly E, Vaillant E, Benmezroua Y, Durand E, Bakaher N, Delannoy V, Vaxillaire M, Cook T, DallingaThie GM, Jansen H, Charles MA, Clement K, Galan P, Hercberg S, Helbecque N, Charpentier G, Prentki M, Hansen T, Pedersen O, Urrutia R, Melloul D, Froguel P: Role of transcription factor KLF11 and its diabetes-associated gene variants in pancreatic beta cell function. Proc Natl Acad Sci USA 2005;102: 4807-4812.

-12 Karasik A, O'Hara C, Srikanta S, Swift M, Soeldner JS, Kahn CR, Herskowitz RD: Genetically programmed selective islet betacell loss in diabetic subjects with Wolfram's syndrome. Diabetes Care 1989;12:135-138.

-13 Pilz D, Quarrell OW, Jones EW: Mitochondrial mutation commonly associated with Leber's hereditary optic neuropathy observed in a patient with Wolfram syndrome (DIDMOAD). J Med Genet 1994;31:328 330.

14 Hofmann S, Bezold R, Jaksch M, ObermaierKusser B, Mertens S, Kaufhold P, Rabl W, Hecker W, Gergitz K: Wolfram (DIDMOAD) syndrome and Leber hereditary optic neuropathy (LHON) are associated with distinct mitochondrial DNA haplotypes. Genomics 1997;39:8-18.

-15 Inoue H, Tanizawa Y, Wasson J, Behn P, Kalidas K, Bernal-Mizrachi E, Mueckler M, Marshall H, Donis-Keller H, Crock P, Rogers D, Mikuni M, Kumashiro H, Higashi K, Sobue G, Oka Y, Permutt MA: A gene encoding a transmembrane protein is mutated in patients with diabetes mellitus and optic atrophy (Wolfram syndrome). Nat Genet 1998; 20:143-148.

-16 Kadowaki T, Kadowaki H, Mori Y, Tobe K, Sakuta R, Suzuki Y, Tanabe Y, Sakura H, Awata T, Goto Y, Hayakawa T, Matsuoka K, Kawamori R, Kamada T, Horai S, Nonaka I,
Hagura R, Akanuma Y, Yazaki Y: A subtype of diabetes mellitus associated with a mutation of mitochondrial DNA. N Engl J Med 1994;330:962-968.

17 Concannon P, Erlich HA, Julier C, Morahan G, Nerup J, Pociot F, Todd JA, Rich SS: Type 1 diabetes: evidence for susceptibility loci from four genome-wide linkage scans in 1,435 multiplex families. Diabetes 2005;54: 2995-3001.

18 Kawasaki E, Matsuura N, Eguchi K: Type 1 diabetes in Japan. Diabetologia 2006;49: 828-836.

19 Eisenbarth GS: Type I diabetes mellitus: a chronic autoimmune disease. N Engl J Med 1986;314:1360-1368.

20 Verge CF, Gianani R, Kawasaki E, Yu L, Pietropaolo M, Jackson RA, Chase HP, Eisenbarth GS: Number of autoantibodies (against insulin, GAD or ICA512/IA2) rather than particular autoantibody specificities determines risk of type I diabetes. J Autoimmun 1996;9:379-383.

21 Verge CF, Gianani R, Kawasaki E, Yu L, Pietropaolo M, Jackson RA, Chase HP, Eisenbarth GS: Prediction of type I diabetes in first-degree relatives using a combination of insulin, GAD, and ICA512bdc/IA-2 autoantibodies. Diabetes 1996;45:926-933.

22 Afzali B, Lombardi G, Lechler RI, Lord GM, Furuzawa-Carballeda J, Vargas-Rojas MI, Cabral AR, Weaver CT, Harrington LE, Mangan PR, Gavrieli M, Murphy KM, Bettelli E, Carrier Y, Gao W, Korn T, Strom TB, Oukka M, Weiner HL, Kuchroo VK: The role of $\mathrm{T}$ helper 17 (Th17) and regulatory $\mathrm{T}$ cells (Treg) in human organ transplantation and autoimmune disease. Clin Exp Immunol 2007; 148:32-46.

23 Furuzawa-Carballeda J, Vargas-Rojas MI, Cabral AR, Weaver CT, Harrington LE, Mangan PR, Gavrieli M, Murphy KM, Bettelli E, Carrier Y, Gao W, Korn T, Strom TB, Oukka M, Weiner HL, Kuchroo VK: Autoimmune inflammation from the Th17 perspective. Autoimmun Rev 2007;6:169-175.

24 Harrington LE, Mangan PR, Weaver CT: Expanding the effector CD4 T-cell repertoire: the Th17 lineage. Curr Opin Immunol 2006; 18:349-356.

25 Pearl-Yafe M, Kaminitz A, Yolcu ES, Yaniv I, Stein J, Askenasy N: Pancreatic islets under attack: cellular and molecular effectors. Curr Pharm Des 2007;13:749-760.

26 Estella E, McKenzie MD, Catterall T, Sutton VR, Bird PI, Trapani JA, Kay TW, Thomas HE: Granzyme B-mediated death of pancreatic beta-cells requires the proapoptotic BH3-only molecule bid. Diabetes 2006;55: 2212-2219.

27 Kawasaki E, Abiru N, Eguchi K: Prevention of type 1 diabetes: from the view point of beta cell damage. Diabetes Res Clin Pract 2004; 66(suppl 1):S27-S32.

28 Itoh N, Hanafusa T, Miyazaki A, Miyagawa J, Yamagata K, Yamamoto K, Waguri M, Imagawa A, Tamura S, Inada M, et al: Mononuclear cell infiltration and its relation to the expression of major histocompatibility complex antigens and adhesion molecules in pancreas biopsy specimens from newly diagnosed insulin-dependent diabetes mellitus patients. J Clin Invest 1993;92:23132322 .

29 Wing K,Suri-PayerE, Rudin A:CD4+CD25+regulatory $\mathrm{T}$ cells from mouse to man. Scand J Immunol 2005;62:1-15.

30 Gambineri E, Torgerson TR, Ochs HD: Immune dysregulation, polyendocrinopathy, enteropathy, and X-linked inheritance (IPEX), a syndrome of systemic autoimmunity caused by mutations of FOXP3, a critical regulator of T-cell homeostasis. Curr Opin Rheumatol 2003;15:430-435

31 Lindley S, Dayan CM, Bishop A, Roep BO, Peakman M, Tree TI: Defective suppressor function in $\mathrm{CD} 44^{+} \mathrm{CD} 25^{+}$T-cells from patients with type 1 diabetes. Diabetes 2005;54: 92-99.

32 Brusko TM, Wasserfall CH, Clare-Salzler MJ, Schatz DA, Atkinson MA: Functional defects and the influence of age on the frequency of CD $4+$ CD25+ T-cells in type 1 diabetes. Diabetes 2005;54:1407-1414.

33 Makino H, Kashihara N, Sugiyama H, Kanao K, Sekikawa T, Okamoto K, Maeshima Y, Ota Z, Nagai R: Phenotypic modulation of the mesangium reflected by contractile proteins in diabetes. Diabetes 1996;45:488495.

34 Mauer SM, Steffes MW, Ellis EN, Sutherland DE, Brown DM, Goetz FC: Structural-functional relationships in diabetic nephropathy. J Clin Invest 1984;74:1143-1155.

35 Mundel P, Shankland SJ: Podocyte biology and response to injury. J Am Soc Nephrol 2002;13:3005-3015.

36 Steffes MW, Schmidt D, McCrery R, Basgen JM: Glomerular cell number in normal subjects and in type 1 diabetic patients. Kidney Int 2001;59:2104-2113.

37 Pagtalunan ME, Miller PL, Jumping-Eagle S, Nelson RG, Myers BD, Rennke HG, Coplon NS, Sun L, Meyer TW: Podocyte loss and progressive glomerular injury in type II diabetes. J Clin Invest 1997;99:342-348.

38 Aaltonen P, Luimula P, Aström E, Palmen T, Grönholm T, Palojoki E, Jaakkola I, Ahola H, Tikkanen I, Holthöfer H: Changes in the expression of nephrin gene and protein in experimental diabetic nephropathy. Lab Invest 2001;81:1185-1190.

39 Doublier S, Salvidio G, Lupia E, Ruotsalainen V, Verzola D, Deferrari G, Camussi G: Nephrin expression is reduced in human diabetic nephropathy: evidence for a distinct role for glycated albumin and angiotensin II. Diabetes 2003;52:1023-1030.

40 Mifsud SA, Allen TJ, Bertram JF, Hulthen UL, Kelly DJ, Cooper ME, Wilkinson-Berka JL, Gilbert RE: Podocyte foot process broadening in experimental diabetic nephropathy: amelioration with renin-angiotensin blockade. Diabetologia 2001;44:878-882.

41 Gross ML, El-Shakmak A, Szabo A, Koch A, Kuhlmann A, Munter K, Ritz E, Amann K: ACE-inhibitors but not endothelin receptor blockers prevent podocyte loss in early diabetic nephropathy. Diabetologia 2003;46: $856-868$. 
-42 Ferrara N: Vascular endothelial growth factor and the regulation of angiogenesis. $\mathrm{Re}$ cent Prog Horm Res 2000;55:15-35.

-43 Cooper ME, Vranes D, Youssef S, Stacker SA, Cox AJ, Rizkalla B, Casley DJ, Bach LA, Kelly DJ, Gilbert RE: Increased renal expression of vascular endothelial growth factor (VEGF) and its receptor VEGFR-2 in experimental diabetes. Diabetes 1999;48:2229-2239.

-44 Tsuchida K, Makita Z, Yamagishi S, Atsumi T, Miyoshi H, Obara S, Ishida M, Ishikawa S, Yasumura K, Koike T: Suppression of transforming growth factor beta and vascular endothelial growth factor in diabetic nephropathy in rats by a novel advanced glycation end product inhibitor, OPB-9195. Diabetologia 1999;42:579-588.

-45 Wendt TM, Tanji N, Guo J, Kislinger TR, Qu W, Lu Y, Bucciarelli LG, Rong LL, Moser B, Markowitz GS, Stein G, Bierhaus A, Liliensiek B, Arnold B, Nawroth PP, Stern DM, D'Agati VD, Schmidt AM: RAGE drives the development of glomerulosclerosis and implicates podocyte activation in the pathogenesis of diabetic nephropathy. Am J Pathol 2003;162:1123-1137.

-46 Andersen AR, Christiansen JS, Andersen JK, Kreiner S, Deckert T: Diabetic nephropathy in type 1 (insulin-dependent) diabetes: an epidemiological study. Diabetologia 1983; 25:496-501.

-47 Krolewski AS, Warram JH, Christlieb AR, Busick EJ, Kahn CR: The changing natural history of nephropathy in type I diabetes. Am J Med 1985;78:785-794.

48 Seaquist ER, Goetz FC, Rich S, Barbosa J: Familial clustering of diabetic kidney disease. Evidence for genetic susceptibility to diabetic nephropathy. N Engl J Med 1989;320:11611165.

-49 Borch-Johnsen K, Norgaard K, Hommel E, Mathiesen ER, Jensen JS, Deckert T, Parving $\mathrm{HH}$ : Is diabetic nephropathy an inherited complication? Kidney Int 1992;41:719-722.

50 Quinn M, Angelico MC, Warram JH, Krolewski AS: Familial factors determine the development of diabetic nephropathy in patients with IDDM. Diabetologia 1996;39: 940-945.

-51 Imperatore G, Hanson RL, Pettitt DJ, Kobes S, Bennett PH, Knowler WC: Sib-pair linkage analysis for susceptibility genes for microvascular complications among Pima Indians with type 2 diabetes. Pima Diabetes Genes Group. Diabetes 1998;47:821-830.

-52 Moczulski DK, Rogus JJ, Antonellis A, Warram JH, Krolewski AS: Major susceptibility locus for nephropathy in type 1 diabetes on chromosome 3q: results of novel discordant sib-pair analysis. Diabetes 1998;47:11641169.

53 Vardarli I, Baier LJ, Hanson RL, Akkoyun I, Fischer C, Rohmeiss P, Basci A, Bartram CR, Van Der Woude FJ, Janssen B: Gene for susceptibility to diabetic nephropathy in type 2 diabetes maps to $18 \mathrm{q} 22.3-23$. Kidney Int 2002;62:2176-2183.

-54 Iyengar SK, Abboud HE, Goddard KA, Saad MF, Adler SG, Arar NH, Bowden DW, Duggirala R, Elston RC, Hanson RL, Ipp E, Kao
WH, Kimmel PL, Klag MJ, Knowler WC, Meoni LA, Nelson RG, Nicholas SB, Pahl MV, Parekh RS, Quade SR, Rich SS, Rotter JI, Scavini M, Schelling JR, Sedor JR, Sehgal AR, Shah VO, Smith MW, Taylor KD, Winkler CA, Zager PG, Freedman BI; Family Investigation of Nephropathy and Diabetes Research Group: Genome-wide scans for diabetic nephropathy and albuminuria in multiethnic populations: the family investigation of nephropathy and diabetes (FIND). Diabetes 2007;56:1577-1585.

55 Shimazaki A, Kawamura Y, Kanazawa A, Sekine A, Saito S, Tsunoda T, Koya D, Babazono T, Tanaka Y, Matsuda M, Kawai K, Iiizumi T, Imanishi M, Shinosaki T, Yanagimoto T, Ikeda M, Omachi S, Kashiwagi A, Kaku K, Iwamoto Y, Kawamori R, Kikkawa R, Nakajima M, Nakamura Y, Maeda S: Genetic variations in the gene encoding ELMO1 are associated with susceptibility to diabetic nephropathy. Diabetes 2005;54:1171-1178.

56 Nishiyama K, Tanaka Y, Nakajima K, Mokubo A, Atsumi Y, Matsuoka K, Watada $H$, Hirose $T$, Nomiyama $T$, Maeda $S$, Kawamori R: Polymorphism of the solute carrier family 12 (sodium/chloride transporters) member 3, SLC12A3, gene at exon 23 (+78G/A: Arg913Gln) is associated with elevation of urinary albumin excretion in Japanese patients with type 2 diabetes: a 10 year longitudinal study. Diabetologia 2005; 48:1335-1338.

57 Ewens KG, George RA, Sharma K, Ziyadeh FN, Spielman RS: Assessment of 115 candidate genes for diabetic nephropathy by transmission/disequilibrium test. Diabetes 2005; 54:3305-3318.

58 Kanesaki Y, Suzuki D, Uehara G, Toyoda M, Katoh T, Sakai H, Watanabe T: Vascular endothelial growth factor gene expression is correlated with glomerular neovascularization in human diabetic nephropathy. Am J Kidney Dis 2005;45:288-294.

59 Satchell SC, Anderson KL, Mathieson PW: Angiopoietin 1 and vascular endothelial growth factor modulate human glomerular endothelial cell barrier properties. J Am Soc Nephrol 2004; 15:566-574.

60 Tsilibary EC: Microvascular basement membranes in diabetes mellitus. J Pathol 2003; 200:537-546.

61 de Vriese AS, Tilton RG, Elger M, Stephan CC, Kriz W, Lameire NH: Antibodies against vascular endothelial growth factor improve early renal dysfunction in experimental diabetes. J Am Soc Nephrol 2001;12:993-1000.

62 Flyvbjerg A, Dagnaes-Hansen F, de Vriese AS, Schrijvers BF, Tilton RG, Rasch R: Amelioration of long-term renal changes in obese type 2 diabetic mice by a neutralizing vascular endothelial growth factor antibody. Diabetes 2002;51:3090-3094.

63 Ichinose K, Maeshima Y, Yamamoto Y, Kitayama H, Takazawa Y, Hirokoshi K, Sugiyama H, Yamasaki Y, Eguchi K, Makino H: Antiangiogenic endostatin peptide ameliorates renal alterations in the early stage of a type 1 diabetic nephropathy model. Diabetes 2005; 54:2891-2903.
64 Yamamoto Y, Maeshima Y, Kitayama H, Kitamura S, Takazawa Y, Sugiyama H, Yamasaki Y, Makino H: Tumstatin peptide, an inhibitor of angiogenesis, prevents glomerular hypertrophy in the early stage of diabetic nephropathy. Diabetes 2004;53:1831-1840.

65 Ichinose K, Maeshima Y, Yamamoto Y, Kinomura M, Hirokoshi K, Kitayama H, Takazawa Y, Sugiyama H, Yamasaki Y, Agata N, Makino H: 2-(8-Hydroxy-6-methoxy-1-oxo1h-2-benzopyran-3-yl) propionic acid, an inhibitor of angiogenesis, ameliorates renal alterations in obese type 2 diabetic mice. $\mathrm{Di}$ abetes 2006;55:1232-1242.

66 Stagner J, Mokshagundam S, Wyler K, Samols E, Rilo H, Stagner M, Parthasarathy L, Parthasarathy R: Beta-cell sparing in transplanted islets by vascular endothelial growth factor. Transplant Proc 2004;36: 1178-1180.

67 Zhang N, Richter A, Suriawinata J, Harbaran S, Altomonte J, Cong L, Zhang H, Song K, Meseck M, Bromberg J, Dong H: Elevated vascular endothelial growth factor production in islets improves islet graft vascularization. Diabetes 2004;53:963-970.

68 Lammert E, Cleaver O, Melton D: Induction of pancreatic differentiation by signals from blood vessels. Science 2001;294:564-567.

69 Suri C, Jones PF, Patan S, Bartunkova S, Maisonpierre PC, Davis S, Sato TN, Yancopoulos GD: Requisite role of angiopoietin-1, a ligand for the TIE2 receptor, during embryonic angiogenesis. Cell 1996;87:1171-1180.

70 Hammes HP, Lin J, Wagner P, Feng Y, Vom Hagen F, Krzizok T, Renner O, Breier G, Brownlee M, Deutsch U: Angiopoietin-2 causes pericyte dropout in the normal retina: evidence for involvement in diabetic retinopathy. Diabetes 2004;53:1104-1110.

71 Sharma K, Jin Y, Guo J, Ziyadeh FN: Neutralization of TGF- $\beta$ by anti-TGF- $\beta$ antibody attenuates kidney hypertrophy and the enhanced extracellular matrix gene expression in STZ-induced diabetic mice. Diabetes 1996;45:522-530.

72 Wang SN, LaPage J, Hirschberg R: Role of glomerular ultrafiltration of growth factors in progressive interstitial fibrosis in diabetic nephropathy. Kidney Int 2000;57:10021014.

73 Ziyadeh FN, Hoffman BB, Han DC, IglesiasDe La Cruz MC, Hong SW, Isono M, Chen S, McGowan TA, Sharma K: Long-term prevention of renal insufficiency, excess matrix gene expression, and glomerular mesangial matrix expansion by treatment with monoclonal antitransforming growth factor-beta antibody in $\mathrm{db} / \mathrm{db}$ diabetic mice. Proc Natl Acad Sci USA 2000;97:8015-8020.

74 Razzaque MS, Kumatori A, Harada T, Taguchi T: Coexpression of collagens and collagen-binding heat shock protein 47 in human diabetic nephropathy and IgA nephropathy. Nephron 1998;80:434-443.

75 Ito Y, Aten J, Bende RJ, Oemar BS, Rabelink TJ, Weening JJ, Goldschmeding R: Expression of connective tissue growth factor in human renal fibrosis. Kidney Int 1998;53:853861. 
-76 Wahab NA, Yevdokimova N, Weston BS, Roberts T, Li XJ, Brinkman H, Mason RM: Role of connective tissue growth factor in the pathogenesis of diabetic nephropathy. Biochem J 2001;359:77-87.

77 Taguchi T, Razzaque MS: The collagen-specific molecular chaperone HSP47: is there a role in fibrosis? Trends Mol Med 2007;13: 45-53.

78 Bending JJ, Lobo-Yeo A, Vergani D, Biberti G: Proteinuria and activated T-lymphocytes in diabetic neuropathy. Diabetes 1988;37: 507-511.

-79 Moriya R, Manivel JC, Mauer M: Juxtaglomerular apparatus T-cell infiltration affects glomerular structure in type 1 diabetic patients. Diabetologia 2004;47:82-88.

-80 Imani F, Horii Y, Suthanthiran M, Skolnik EY, Makita Z, Sharma V, Sehajpal P, Vlassara $\mathrm{H}$ : Advanced glycosylation endproduct-specific receptors on human and rat T-lymphocytes mediate synthesis of interferon gamma: role in tissue remodeling. J Exp Med 1993; 178:2165-2172.

-81 Moriwaki Y, Yamamoto T, Shibutani Y, Aoki E, Tsutsumi Z, Takahashi S, Okamura $\mathrm{H}$, Koga M, Fukuchi M, Hada T: Elevated levels of interleukin-18 and tumor necrosis factoralpha in serum of patients with type 2 diabetes mellitus: relationship with diabetic nephropathy. Metabolism 2003;52:605-608.

-82 Mahmoud RA, el-Ezz SA, Hegazy AS: Increased serum levels of interleukin-18 in patients with diabetic nephropathy. Ital J Biochem 2004;53:73-81.

-83 Lin HY, Wang CL, Hsiao PJ, Lu YC, Chen SY, Lin KD, Hsin SC, Hsieh MC, Shin SJ: SUMO4 $\mathrm{M} 55 \mathrm{~V}$ variant is associated with diabetic nephropathy in type 2 diabetes. Diabetes 2007; 56:1177-1180.

84 Yang B, Houlberg K, Millward A, Demaine A: Polymorphisms of chemokine and chemokine receptor genes in type 1 diabetes mellitus and its complications. Cytokine 2004;26:114-121.

-85 Ma J, Mollsten A, Prazny M, Falhammar H, Brismar K, Dahlquist G, Efendic S, Gu HF: Genetic influences of the intercellular adhesion molecule 1 (ICAM-1) gene polymorphisms in development of type 1 diabetes and diabetic nephropathy. Diabet Med 2006; 23:1093-1099.

-86 Patel A, Scott WR, Lympany PA, Rippin JD, Gill GV, Barnett AH, Bain SC; Warren 3/UK GoKind Study Group: The TGF-beta 1 gene codon 10 polymorphism contributes to the genetic predisposition to nephropathy in type 1 diabetes. Diabet Med 2005;22:69-73.

-87 Del Bo R, Scarlato M, Ghezzi S, Maestroni A, Sjolind L, Forsblom C, Wessman M, Groop PH, Comi GP, Bresolin N, Luzi L, Zerbini G: VEGF gene variability and type 1 diabetes: evidence for a protective role. Immunogenetics 2006;58:107-112.
Thiel S, Vorup-Jensen T, Stover CM, Schwae ble W, Laursen SB, Poulsen K, Willis AC Eggleton P, Hansen S, Holmskov U, Reid KB Jensenius JC: A second serine protease associated with mannan-binding lectin that activates complement. Nature 1997;386:506510 .

89 Bouwman LH, Eerligh P, Terpstra OT, Daha $\mathrm{MR}$, de Knijff P, Ballieux BE, Bruining GJ, van der Slik AR, Roos A, Roep BO: Elevated levels of mannose-binding lectin at clinical manifestation of type 1 diabetes in juveniles. Diabetes 2005;54:3002-3006.

-90 Saraheimo M, Forsblom C, Hansen TK, Teppo AM, Fagerudd J, Pettersson-Fernholm K, Thiel S, Tarnow L, Ebeling P, Flyvbjerg A Groop PH: Increased levels of mannan-binding lectin in type 1 diabetic patients with incipient and overt nephropathy. Diabetologia 2005;48:198-202.

$91 \mathrm{Kim}$ JH, Shin HD, Park BL, Moon MK, Cho YM, Hwang YH, Oh KW, Kim SY, Lee HK, Ahn C, Park KS: SLC12A3 (solute carrier family 12 member [sodium/chloride] 3) polymorphisms are associated with endstage renal disease in diabetic nephropathy. Diabetes 2006;55:843-848.

92 Tanaka N, Babazono T, Saito S, Sekine A, Tsunoda T, Haneda M, Tanaka Y, Fujioka T, Kaku K, Kawamori R, Kikkawa R, Iwamoto Y, Nakamura Y, Maeda S: Association of solute carrier family 12 (sodium/chloride) member 3 with diabetic nephropathy, identified by genome-wide analyses of single nucleotide polymorphisms. Diabetes 2003;52: 2848-2853.

93 Shimazaki A, Tanaka Y, Shinosaki T, Ikeda M, Watada H, Hirose T, Kawamori R, Maeda S: ELMO1 increases expression of extracellular matrix proteins and inhibits cell adhesion to ECMs. Kidney Int 2006;70:1769 1776.

94 Balasa B, La Cava A, Van Gunst K, Mocnik L, Balakrishna D, Nguyen N, Tucker L, Sarvetnick N: A mechanism for IL-10-mediated diabetes in the nonobese diabetic (NOD) mouse: ICAM-1 deficiency blocks accelerated diabetes. J Immunol 2000;165:73307337.

95 Sugimoto H, Shikata K, Hirata K, Akiyama K, Matsuda M, Kushiro M, Shikata Y, Miyatake N, Miyasaka M, Makino H: Increased expression of intercellular adhesion molecule-1 (ICAM-1) in diabetic rat glomeruli: glomerular hyperfiltration is a potential mechanism of ICAM-1 upregulation. Diabetes 1997;46:2075-2081.
96 Matsui H, Suzuki M, Tsukuda R, Iida K, Miyasaka M, Ikeda H: Expression of ICAM1 on glomeruli is associated with progression of diabetic nephropathy in a genetically obese diabetic rat, Wistar fatty. Diabetes Res Clin Pract 1996;32:1-9.

-97 Yang B, Cross DF, Ollerenshaw M, Millward BA, Demaine AG: Polymorphisms of the vascular endothelial growth factor and susceptibility to diabetic microvascular complications in patients with type 1 diabetes mellitus. J Diabetes Complications 2003; 17:1-6.

98 Hansen TK, Tarnow L, Thiel S, Steffensen $\mathrm{R}$, Stehouwer CD, Schalkwijk CG, Parving $\mathrm{HH}$, Flyvbjerg A: Association between mannose-binding lectin and vascular complications in type 1 diabetes. Diabetes 2004; 53:1570-1576

99 Hovind P, Hansen TK, Tarnow L, Thiel S, Steffensen R, Flyvbjerg A, Parving $\mathrm{HH}$ : Mannose-binding lectin as a predictor of microalbuminuria in type 1 diabetes: an inception cohort study. Diabetes 2005;54: 1523-1527.

100 Bohren KM, Nadkarni V, Song JH, Gabbay $\mathrm{KH}$, Owerbach D: A M55V polymorphism in a novel SUMO gene (SUMO-4) differentially activates heat shock transcription factors and is associated with susceptibility to type I diabetes mellitus. J Biol Chem 2004; 279:27233-27238.

101 Wang Y, Ng MC, So WY, Ma R, Ko GT, Tong PC, Chan IC: Association between tumour necrosis factor-alpha G-308A polymorphism and risk of nephropathy in obese Chinese type 2 diabetic patients. Nephrol Dial Transplant 2005;20:2733-2738.

102 Hotamisligil GS, Arner P, Caro JF, Atkinson RL, Spiegelman BM: Increased adipose tissue expression of tumor necrosis factoralpha in human obesity and insulin resistance. J Clin Invest 1995;95:2409-2415.

103 Shankland SJ, Scholey JW, Ly H, Thai K: Expression of transforming growth factorbeta 1 during diabetic renal hypertrophy. Kidney Int 1994;46:430-442.

104 Iwano M, Kubo A, Nishino T, Sato H, Nishioka H, Akai Y, Kurioka H, Fujii Y, Kanauchi M, Shiiki H, Dohi K: Quantification of glomerular TGF-beta 1 mRNA in patients with diabetes mellitus. Kidney Int 1996;49: 1120-1126.

105 Hill C, Flyvbjerg A, Gronbaek H, Petrik J, Hill DJ, Thomas CR, Sheppard MC, Logan A: The renal expression of transforming growth factor-beta isoforms and their receptors in acute and chronic experimental diabetes in rats. Endocrinology 2000;141: 1196-1208.

- 106 Ihm CG, Park JK, Hong SP, Lee TW, Cho BS, Kim MJ, Cha DR, Ha H: A high glucose concentration stimulates the expression of monocyte chemotactic peptide 1 in human mesangial cells. Nephron 1998;79:33-37. 